\title{
Bekerja dari Rumah (Working From Home/WFH): Menuju Tatanan Baru Era Pandemi COVID 19
}

\author{
Oswar Mungkasa ${ }^{1}$ \\ Kementerian Perencanaan Pembangunan Nasional/Bappenas Republik Indonesia
}

\begin{abstract}
Abstraksi
Skema Work From Home (WFH) merupakan bagian dari konsep telecommuting (bekerja jarak jauh), yang merupakan hal biasa dalam dunia kerja dan perencanaan kota. Walaupun demikian, konsep ini biasanya diberlakukan dalam kondisi normal dan bukan karena adanya pandemik seperti sekarang ini. Makalah ini berupaya memberikan gambaran tentang konsep telecommuting (bekerja jarak jauh) atau working from home/WFH (bekerja dari rumah) berikut pembelajarannya, disertai langkah yang perlu dilakukan oleh seluruh pemangku kepentingan baik pemerintah, swasta maupun masyarakat umum. Agar kemudian penerapannya dalam jangka panjang dapat lebih optimal ketika kita semua dapat memahami, mengantisipasi dan beradaptasi dengan lebih baik terhadap konsep ini. Konsep ini diharapkan dapat menjadi bagian dari tatanan baru (new normal) dari kehidupan keseharian kita sehingga penerapan telecommuting menjadi suatu keniscayaan.
\end{abstract}

Kata kunci: bekerja dari rumah, bekerja jarak jauh, new normal, covid-19

\footnotetext{
${ }^{1}$ Oswar Mungkasa adalah Perencana Madya di Kementerian Perencanaan Pembangunan Nasional/Bappenas Republik Indonesia. E-mail: oswar.mungkasa63@gmail.com
} 
Oswar Mungkasa

\title{
Bekerja dari Rumah (Working From Home/WFH): Menuju Tatanan Baru Era Pandemi COVID 19
}

\author{
Oswar Mungkasa
}

\section{Pendahuluan}

Sejak merebaknya Covid-19 di Wuhan pada awal tahun 2020, kehebohan mulai menyeruak secara berangsur yang bahkan menjangkau seluruh dunia. Kehebohan ini dipicu oleh banyaknya jumlah korban dalam waktu relatif singkat disertai kegamangan semua pihak menghadapi Covid-19.

Berbagai negara kemudian mulai menerapkan Protokol Covid-19 sesuai dengan anjuran World Health Organization (WHO), mulai dari cuci tangan, tidak berkumpul/melakukan pertemuan, menjaga jarak, membatasi keluar rumah bahkan dilakukan langkah isolasi mulai isolasi mandiri perorangan, komunitas, bahkan seluruh kota (mulai dari Pembatasan Sosial Berskala Besar/PSBB sampai lock down). Sebagai akibatnya banyak kantor baik pemerintah maupun swasta yang kemudian menerapkan skema bekerja dari rumah (Working from Home/WFH).

Skema WFH merupakan bagian dari konsep telecommuting (bekerja jarak jauh)², yang sebenarnya bukan hal baru dalam dunia kerja dan perencanaan kota, bahkan telah dikenal sejak tahun 1970-an sebagai salah satu upaya mengatasi kemacetan lalulintas dari perjalanan rumah-kantor pulang-pergi setiap hari.

Walaupun demikian, konsep ini biasanya diberlakukan dalam kondisi normal dan bukan karena adanya pandemik seperti sekarang ini. Apalagi kemudian ditengarai kondisi saat ini akan berlangsung setidaknya sampai ditemukan vaksin yang diperkirakan paling cepat akhir tahun 2021. Sampai saat itu dan bahkan ditengarai dapat menjadi bagian dari tatanan baru (new normal) dari kehidupan keseharian kita sehingga penerapan telecommuting menjadi suatu keniscayaan.

Mengantisipasi kondisi ini, tulisan ini berupaya memberikan gambaran tentang konsep telecommuting (bekerja jarak jauh) atau working from home/WFH (bekerja dari rumah) berikut pembelajarannya, disertai langkah yang perlu dilakukan oleh seluruh pemangku kepentingan baik pemerintah, swasta maupun masyarakat umum. Agar kemudian penerapannya dalam jangka panjang dapat lebih optimal ketika kita semua dapat memahami, mengantisipasi dan beradaptasi dengan lebih baik terhadap konsep ini.

\section{Bekerja Jarak Jauh: Sejarah, Konsep, dan Perkembangan Terkini ${ }^{3}$}

\subsection{Sejarah Awal Perkembangan}

Istilah bekerja jarak jauh pertama kali muncul dalam buku The Human Use of Human Beings Cybernetics and Society oleh Norbert Wiener pada tahun 1950 yang menggunakan

\footnotetext{
${ }^{2}$ Istilah telecommuting (bekerja jarak jauh) dan working from home/WFH (bekerja dari rumah) dipergunakan bergantian dengan arti yang sama hanya berbeda konteks.

${ }^{3}$ Materi pada bagian ini dirangkum dari tulisan penulis berjudul Bekerja Jarak Jauh (Telecommuting). Konsep, Penerapan dan Pembelajaran. 2020.
} 
istilah telework (istilah yang popular di Eropa sampai saat ini) (Siddharta dan Malika, 2016). Selanjutya pada tahun 1974, istilah 'telecommute' dipergunakan pertama kali dalam laporan University of Southern California yang berfokus pada proyek pengurangan lalu lintas jam puncak yang dibiayai oleh the National Science Foundation (Nilles dkk, 1974).

Pada tahun 1980, Alvin Toffler memperkenalkan ide bekerja jarak jauh (telework) dalam 3 (tiga) tahap berdasar munculnya "the third wave" (Siddhartha dan Malika, 2016). Dimulai pada tahun 1970 sebagai jawaban upaya pengurangan penglaju (commuting) dan konsumsi energi, tahun 1980 bekerja jarak jauh bangkit kembali sebagai pengaturan bekerja leluasa (fleksibel), yang memungkinkan tercipta keseimbangan bekerja dan kehidupan keluarga, kekurangan tenaga terampil terpenuhi, dan ekonomi kawasan pinggiran terpadu dengan pusat kota (Kinsman 1987; Huws dkk. 1990). Pada tahun 1990an, perhatian lebih banyak terhadap isu desain tempat kerja, pengelolaan fasilitas dan kebutuhan mengelola waktu kerja dan ruang kerja untuk mendorong produktivitas dan efektivitas (Jackson, dan Wielen ed., 1998).

Di Amerika Serikat, diskusi bekerja jarak jauh lebih dulu dari Eropa, yang dimulai oleh 'Nabi bekerja jarak jauh’ Jack Nilles pada tahun 1973. Analisis sistematik tentang pro dan kontra bekerja jarak jauh dipublikasikan pada tahun 1976 oleh Nilles dibantu oleh Carlson, Gray and Hanneman (Nilles dkk., 1976). Laporan tersebut menyangkut manfaat dan biaya ekonomi perjalanan ke dan dari kantor dibandingkan dengan biaya dan manfaat bekerja dari rumah.

Sepanjang dekade 70 sampai 80, bekerja jarak jauh di Eropa masih dipandang sebelah mata. Pada waktu itu, 'telework' sering disebut dengan istilah 'electronic homework', bermakna pekerjaan kantor rendahan dari rumah, baik berdasar kontrak penuh waktu atau paruh waktu. Umumnya berkonotasi negatif. Pekerja jarak jauh dicontohkan sebagai ibu rumah tangga yang mempunyai anak, terpisah dari komunitas kantor, mengerjakan pekerjaan monoton bagi pemberi kerja. Literatur kritis menggunakan istilah 'electronic homework' sebagai ganti 'telework' untuk menekankan kondisi awal industri rumahan. Berdasar analisis kritis, wanita berpotensi menjadi pekerja jarak jauh (Jackson dan Wielen ed., 1998)

Konsep bekerja jarak jauh mulai mendapat perhatian banyak pihak pada akhir abad 20, menyertai kemunculan teknologi komunikasi dan komputer pribadi. Istilah telecommuting atau "telework" makin dikenal pada tahun 80-an ketika para pekerja diberi kesempatan untuk menyelesaikan tugas dari rumah dibandingkan dengan datang langsung ke kantor (Potter, 2003). Pada saat itu, penerapan pekerjaan secara telecommuting (bekerja jarak jauh) diberlakukan satu hari dalam seminggu (Siha dan Monroe, 2006).

Pada dekade yang sama, program uji coba bekerja jarak jauh dimulai pada berbagai lokasi di Amerika Serikat dan pada tahun 1990-an banyak negara bagian, pemerintah daerah, dan perusahaan telah menerapkan sistem bekerja jarak jauh. Didorong oleh perkembangan teknologi informasi dan persaingan bisnis internasional, lebih banyak lagi organisasi yang menerapkan bekerja jarak jauh (Asgari, 2015).

Pemerintah Federal Amerika Serikat baru membuka pilihan bekerja jarak jauh secara resmi pada awal tahun 90-an. Penerapannya kemudian teruji baik pada peristiwa 911 tahun 2011 ketika teroris menyerang Pentagon dan the World Trade Center. Kebijakan umum dan 
petunjuk Pelaksanaan Program Bekerja Jarak Jauh bagi Eksekutif telah diluncurkan oleh General Service Administration (GSA) dan the Office of Personnel Management (OPM).

\subsection{Keragaman istilah}

Penamaan konsep bekerja jarak jauh sendiri beragam tetapi hanya beberapa yang masih sering dipergunakan. Awalnya istilah yang dipergunakan adalah 'electronic homework' yang terdengar kuno sekarang. Istilahnya berkembang menjadi 'telecommuting', menggunakan konsep Jack Nilles pada tahun 1973, karena terkait erat dengan penglaju dari rumah ke kantor berikut masalah kemacetannya (Nilles dkk. 1976). Kemudian 'flexiwork', sebuah istilah yang lebih dikenal di Eropa.

Penamaan yang beragam ini disesuaikan dengan fokus dari penerapan bekerja jarak jauh. Penggunaan istilah flexy (flexywork, flexibility working) dengan mempertimbangkan kondisi keleluasaan dalam bekerja, yang artinya jam kerja disesuaikan dengan kondisi yang ada. Lainnya seperti 'homework', 'alternative officing' dan 'mobile working' berdasarkan keragaman bentuk bekerja jarak jauh misal bekerja dari rumah dengan kantor pusat, gabungan bekerja pada kantor pusat dan kantor cabang, dan nomaden tanpa kantor (Stanworth dan Stanworth, 1991; dan Gordon, 1996).

\subsection{Pemahaman Dasar}

Beragam pengertian dapat ditemui dalam literatur, tetapi sepertinya pengertian oleh Huuhtanen (1997) yang relatif mudah dipahami, yaitu pekerjaan yang dilakukan oleh seseorang (pegawai, pekerja mandiri, pekerja rumahan) secara khusus, atau hanya waktu tertentu, pada sebuah lokasi jauh dari kantor, menggunakan media telekomunikasi sebagai alat kerja. Ditambahkan oleh Konradt, Schmook, dan Malecke (2000), bahwa bekerja jarak jauh dimaksudkan sebagai cara bekerja dalam sebuah organisasi yang dilaksanakan sebagian atau seluruhnya di luar kantor konvensional dengan bantuan layanan telekomunikasi dan informasi (DeRossette, 2016).

Pengamatan sekilas menunjukkan bahwa pemahaman bekerja jarak jauh setidaknya menyangkut 4 (empat) hal yaitu

(i) pilihan tempat kerja, yang mengacu pada penghematan waktu/jarak fisik (tele);

(ii) sebagian atau substitusi total dari penglaju (commute) harian;

(iii) intensitas aktivitas bekerja jarak jauh, yang mengacu pada kekerapan dan lamanya waktu;

(iv) ketersediaan teknologi komunikasi dan informasi (Mungkasa, 2020).

\subsection{Keragaman Bentuk}

Bentuk yang paling mudah dikenali dari bekerja jarak jauh adalah bekerja dari rumah (home-based telecommuting) dan bekerja dari kantor cabang (center-based telecommuting). Seperti namanya, bekerja dari rumah menunjukkan lokasi kerja di rumah dengan berkomunikasi ke kantor, sementara bekerja dari kantor cabang/satelit menunjukkan lokasi bekerja bukan di rumah tapi di kantor yang terdekat dari rumah. Menggunakan perspektif transportasi, bekerja dari rumah mengurangi sepenuhnya perjalanan penglaju, sementara bekerja dari kantor cabang hanya mengurangi jarak perjalanan (Asgari, 2015). 
Teo dkk. (1998) menggambarkan bekerja jarak jauh sebagai menyelesaikan tugas jauh dari lokasi kantor reguler setidaknya satu sampai dua hari per minggu. Perlu juga diingat bahwa bekerja jarak jauh tidak perlu melibatkan bekerja di rumah, tetapi bisa juga termasuk memanfaatkan pusat bekerja jarak jauh (telework center), berlokasi di luar rumah dan kantor regular.

Penelitian pada tahun 2001, The International Telework Association and Council ITAC2 menemukan bahwa bekerja jarak jauh dapat dilakukan di rumah, jalan, lokasi pelanggan, atau kantor satelit (cabang). Sebagai tambahan, beragam peneliti menyepakati bahwa bekerja jarak jauh mengarah pada substitusi sebagian atau seluruhnya dari penglaju harian (Nilles, 1988; Mokhtarian, 1991; Sampath dkk., 1991; Handy dan Mokhtarian, 1995; Walls dan Safirova, 2004).

Menurut Heathfield (2019) terdapat beragam skema bekerja diantaranya bekerja leluasa (flexible schedule), dan bekerja jarak jauh (telecommuting), tentu saja selain bekerja penuh waktu sampai bekerja sementara. Selanjutnya, bekerja leluasa dimaknai sebagai pekerja dimungkinkan bekerja berbeda dari waktu kerja konvensional sehingga pekerja dapat menyeimbangkan bekerja dan berkehidupan. Bekerja jarak jauh (dari rumah dan/atau lokasi lain di luar kantor) adalah pengaturan bekerja leluasa yang memungkinkan bekerja jauh dari kantor sepanjang atau sebagian waktu (Mungkasa, 2020).

Literatur mengategorikan praktek kerja leluasa (flexible work) sebagai praktek kerja kantoran (office-based) dan lokasi leluasa (flexi-place) (Grobler dan De Bruyn, 2011); atau waktu leluasa (flexitime) dan lokasi leluasa (flexi-place) (Munsch, Ridgeway dan Williams, 2014). Kelly, Moen dan Tranby (2011) mengacu pada keleluasaan terhadap kendali jadwal, sebab pilihan kerja leluasa dapat mencakup kerja darurat (contingent work), kerja kontrak (contract work) dan pegawai sesaat (just-in-time staffing) (Mungkasa, 2020).

Keleluasaan waktu kerja (Flexible Working Time) atau waktu kerja leluasa (Flexi Time) adalah sistem pengaturan kerja yang memberi lebih banyak kebebasan kepada karyawan dalam mengatur jam kerja sendiri. Flexi Time banyak digunakan oleh perusahaan berskala global yang sulit jika harus menyamakan waktu bekerja karena adanya perbedaan zona waktu di beberapa negara. Flexi Time memegang prinsip bahwa jam berapapun karyawan masuk, asalkan pekerjaan selesai dan waktu yang digunakan memenuhi jumlah jam yang sudah disepakati dalam perjanjian kerja. Di bawah ini adalah beberapa jenis Flexi Time yang sering digunakan:

\section{a. Fixed Working Hours}

Sistem kerja yang memungkinkan pegawai dapat bebas memilih sesi kerjanya setiap hari sesuai ketetapan perusahaan sepanjang memenuhi jumlah minimal 40 jam seminggu. Sebagai contoh, perusahaan memberi kebebasan kepada karyawan untuk memilih jam kerja dengan ketentuan 25\% karyawan bekerja pada jam 07.00-15.00; 25\% karyawan bekerja pada jam 08.00-16.00; 25\% karyawan bekerja pada jam 09.0017.00; dan 25\% terakhir dari karyawan bekerja pada jam 10.00-18.00.

\section{b. Flexible Working Hours}

Sistem kerja yang memungkinkan pegawai bekerja leluasa sepanjang memenuhi jumlah waktu minimal adalah 40 jam per minggu. Jumlah jam kerja tidak harus sama setiap harinya. 


\section{c. Variable Working Hours}

Sistem kerja yang mengharuskan pegawai hadir pada jam tertentu di kantor dan pegawai dapat menetapkan sendiri waktu selebihnya. Sebagai contoh, karyawan diwajibkan masuk setiap hari jam 09.00-13.00, dan selebihnya dapat bekerja jarak jauh sampai memenuhi minimal 40 jam seminggu (Ayuna, 2019)

Penelitian lain menyimpulkan terdapat 3 (tiga) kategori bekerja leluasa (flexible work arrangement/FWA) yaitu flexi-time (leluasa jadwal), tele-homeworking (leluasa tempat), dan part time (paruh waktu/leluasa lama bekerja). Dalam kenyataannya ketiganya dapat digabungkan dan saling melengkapi disesuaikan kebutuhan (Possenried dan Plantenga, 2011). Sehingga bekerja leluasa diartikan sebagai kemampuan pekerja mengendalikan sendiri lamanya bekerja, tempat bekerja jauh dari kantor, penjadwalan kerja yang ditawarkan perusahaan (Atkinson dan Hall, 2011).

Walaupun beragam bentuk bekerja jarak jauh, namun secara sederhana, bekerja jarak jauh dapat dikategorikan dalam 3 (tiga) jenis yaitu (i) bekerja di rumah (telecommuting); (ii) bekerja dari kantor cabang yang berlokasi dekat rumah atau kantor satelit (satellite offices); (iii) bekerja di mana saja di luar kantor sesuai kebutuhan (mobile work) (Mungkasa, 2020).

\subsection{Manfaat, Kerugian dan Dampak}

Secara singkat, manfaat bagi pekerja adalah (i) keseimbangan antara bekerja dan kehidupan keluarga; (ii) mengurangi waktu perjalanan ke kantor dan penghematan bahan bakar; (iii) dapat mengendalikan jadwal kerja dan suasana kerja; (iv) dapat memilih bekerja ketika suasana hati sedang baik. Sementara manfaat bagi pemberi kerja adalah (i) mendorong semangat bekerja; (ii) mengurangi kemalasan dan ketidakhadiran; (iii) mengurangi pergantian pekerja; (iv) memperkuat citra perusahaan sebagai tempat bekerja yang ramah keluarga.

Beragam manfaat yang diperoleh dari bekerja jarak jauh namun bukannya tanpa kendala dan masalah. Bagi pekerja beberapa masalah diantaranya adalah (i) pekerja yang terbiasa dengan suasana kantor konvensional menjadi kesulitan dalam berkoordinasi dengan rekan kerja. Dibutuhkan penjadwalan kerja yang lebih rapi bahkan mungkin perlu ditetapkan waktu tetap untuk berkumpul di kantor; (ii) tidak terlihat batasan jelas antara kantor dan rumah, bahkan cenderung waktu kerja menjadi tanpa batasan; (iii) pekerja jarak jauh cenderung terlihat seperti pengangguran dan berdampak pada hubungan dengan tetangga dan keluarga. Keluarga dan tetangga mungkin menjadi marah ketika pekerja jarak jauh tidak ikut serta dalam pekerjaan rumah tangga dan lingkungan walaupun kenyataannya berada di rumah.

Sementara bagi pimpinan perusahaan/organisasi, beberapa kendala yang mungkin timbul diantaranya adalah (i) beberapa pimpinan mengalami kesulitan menyesuaikan diri terutama bagi pimpinan yang cenderung kurang percaya kepada bawahan; (ii) pada pekerjaan yang membutuhkan intensitas kerjasama kelompok yang tinggi, dibutuhkan pengaturan jadwal pertemuan yang akan merepotkan; (iii) jenis pekerjaan yang membutuhkan bertemu langsung dengan pelanggan hanya memungkinkan bekerja leluasa secara terbatas, tidak 
mungkin sepanjang waktu berada jauh dari kantor. Sementara ketika hanya sebagian pekerja yang bisa bekerja jarak jauh maka ini akan menimbulkan rasa ketidakadilan diantara pekerja. (iv) beberapa pekerja tidak dapat bekerja tanpa pengawasan.

Walaupun demikian, manfaat bekerja jarak jauh mengalahkan kelemahan yang dihadapi. Selengkapnya rangkuman manfaat, dan kelemahan dapat dilihat pada Tabel 1 berikut

Tabel 1. Rangkuman Manfaat, dan Kelemahan dari Sudut Pandang Pekerja, Pemberi Kerja dan Masyarakat

\begin{tabular}{|c|c|c|}
\hline Kategori & Manfaat/Kelebihan/Keunggulan & Kelemahan/Kekurangan/Tantangan \\
\hline \multicolumn{3}{|c|}{ Dimensi Ekonomi - Manajemen } \\
\hline \multirow{8}{*}{ Pekerja } & $\begin{array}{l}\text { kemandirian dan keleluasaan } \\
\text { menentukan jadwal kerja }\end{array}$ & $\begin{array}{l}\text { terbatasnya pengayaan belajar } \\
\text { langsung (on-the-job) dan } \\
\text { berkurangnya transfer } \\
\text { pengetahuan secara langsung }\end{array}$ \\
\hline & $\begin{array}{l}\text { - berkurang/hilangnya waktu } \\
\text { perjalanan ke kantor }\end{array}$ & $\begin{array}{l}\text { terbatasnya interaksi dengan } \\
\text { pimpinan yang dapat berdampak } \\
\text { pada karir }\end{array}$ \\
\hline & $\begin{array}{l}\text { Berkurangnya biaya perjalanan, } \\
\text { dan parkir }\end{array}$ & $\begin{array}{l}\text { merasa terisolasi dari jejaring sosial } \\
\text { kantor }\end{array}$ \\
\hline & $\begin{array}{l}\text { meningkatnya semangat, } \\
\text { komitmen bekerja, dan tingkat } \\
\text { kepuasan kerja }\end{array}$ & $\begin{array}{l}\text { merasa tidak disukai oleh rekan } \\
\text { kerja }\end{array}$ \\
\hline & $\begin{array}{l}\text { - terhindarnya dari kasak kusuk } \\
\text { kantor (office politics) }\end{array}$ & $\begin{array}{l}\text { - bertambahnya biaya rumah tangga } \\
\text { baik listrik, pulsa, dan lainnya }\end{array}$ \\
\hline & $\begin{array}{l}\text { - meningkatnya kompetensi dan } \\
\text { kemahiran }\end{array}$ & $\begin{array}{l}\text { - duplikasi peralatan kerja di rumah } \\
\text { dan di kantor }\end{array}$ \\
\hline & $\begin{array}{l}\text { - meningkatnya pendapatan dan } \\
\text { tabungan }\end{array}$ & $\begin{array}{l}\text { tidak tersedianya cukup ruang, } \\
\text { serta suasana yang mendukung } \\
\text { untuk bekerja di rumah }\end{array}$ \\
\hline & & $\begin{array}{l}\text { ketersediaan regulasi yang } \\
\text { memadai }\end{array}$ \\
\hline \multirow{6}{*}{$\begin{array}{l}\text { Pemberi } \\
\text { Kerja }\end{array}$} & $\begin{array}{l}\text { - meningkatnya produktivitas } \\
\text { pekerja dan kualitas pekerjaan }\end{array}$ & $\begin{array}{l}\text { manajer menganggap sebagai } \\
\text { ancaman terhadap identitas, harga } \\
\text { diri dan jabatan }\end{array}$ \\
\hline & $\begin{array}{l}\text { - berkurangnya tingkat } \\
\text { ketidakhadiran dan } \\
\text { keterlambatan }\end{array}$ & - kesulitan memantau kinerja pekerja \\
\hline & $\begin{array}{l}\text { meningkatnya masa kerja } \\
\text { pekerja terutama pekerja } \\
\text { berkualitas }\end{array}$ & $\begin{array}{l}\text { - kesulitan mengukur tingkat } \\
\text { produktivitas pekerja }\end{array}$ \\
\hline & - berkurangnya biaya kantor & $\begin{array}{l}\text { - mendorong perubahan organisasi } \\
\text { keluar dari zona nyaman }\end{array}$ \\
\hline & $\begin{array}{l}\text { pekerja dimungkinkan } \\
\text { bertambah tanpa menambah } \\
\text { luasan kantor }\end{array}$ & $\begin{array}{l}\text { sulit diterapkan untuk organisasi } \\
\text { dengan manajemen yang terpusat }\end{array}$ \\
\hline & $\begin{array}{l}\text { pemanfaatan manajemen } \\
\text { pengetahuan, bekerja jarak } \\
\text { jauh, dan e-learning dapat }\end{array}$ & - kesulitan mendorong sinergitas tim \\
\hline
\end{tabular}




\begin{tabular}{|c|c|c|}
\hline Kategori & Manfaat/Kelebihan/Keunggulan & Kelemahan/Kekurangan/Tantangan \\
\hline & $\begin{array}{l}\text { menghasilkan sinergi dan } \\
\text { manfaat ekonomi }\end{array}$ & \\
\hline & & $\begin{array}{l}\text { peluang berdampak negatif } \\
\text { terhadap melemahnya jejaring } \\
\text { sosial kantor }\end{array}$ \\
\hline & & $\begin{array}{l}\text { - belum dilengkapi legalitas bekerja } \\
\text { jarak jauh }\end{array}$ \\
\hline & & $\begin{array}{l}\text { tambahan biaya untuk transisi } \\
\text { termasuk untuk pelatihan dan } \\
\text { pendampingan }\end{array}$ \\
\hline & & $\begin{array}{l}\text { ketersediaan regulasi yang } \\
\text { memadai }\end{array}$ \\
\hline \multicolumn{3}{|c|}{ Dimensi Lingkungan - Teknologi } \\
\hline \multirow[t]{2}{*}{ Pekerja } & $\begin{array}{l}\text { memungkinkan dengan } \\
\text { teknologi memperoleh data dan } \\
\text { informasi dari luar kantor }\end{array}$ & $\begin{array}{l}\text { tidak tersedia atau kualitas internet } \\
\text { kurang memadai. Termasuk } \\
\text { kehandalan ketersediaan listrik }\end{array}$ \\
\hline & & $\begin{array}{l}\text { perangkat tidak lengkap atau } \\
\text { kurang dukungan teknis }\end{array}$ \\
\hline \multirow{3}{*}{$\begin{array}{l}\text { Pemberi } \\
\text { Kerja }\end{array}$} & $\begin{array}{l}\text { ketersediaan teknologi } \\
\text { memungkinkan memantau } \\
\text { kegiatan dan target pekerja } \\
\text { secara langsung }\end{array}$ & $\begin{array}{l}\text { keamanan data dan informasi } \\
\text { perusahaan dapat terancam }\end{array}$ \\
\hline & $\begin{array}{l}\text { - berkurangnya penggunaan } \\
\text { kertas }\end{array}$ & $\begin{array}{l}\text { - perkembangan teknologi demikian } \\
\text { cepat dapat mengganggu irama } \\
\text { kerja }\end{array}$ \\
\hline & & $\begin{array}{l}\text { ketergantungan pada teknologi } \\
\text { dapat mengalami kegagalan atau } \\
\text { kurang optimal }\end{array}$ \\
\hline \multirow{3}{*}{ Masyarakat } & $\begin{array}{l}\text { - berkurangnya emisi dan } \\
\text { kualitas udara membaik }\end{array}$ & $\begin{array}{l}\text { - mendorong fenomena rebakan kota } \\
\text { (urban sprawl) }\end{array}$ \\
\hline & $\begin{array}{l}\text { - strategi pengelolaan bangkitan } \\
\text { lalulintas (Trvael Demand } \\
\text { Management/TDM) }\end{array}$ & \\
\hline & $\begin{array}{l}\text { - tidak membutuhkan } \\
\text { penambahan rencana dalam } \\
\text { Rencana Tata Ruang } \\
\end{array}$ & \\
\hline \multicolumn{3}{|c|}{ Dimensi Sosial } \\
\hline \multirow{4}{*}{ Pekerja } & $\begin{array}{l}\text { mengurus kepentingan } \\
\text { keluarga dan berkehidupan } \\
\text { dengan lebih nyaman }\end{array}$ & $\begin{array}{l}\text { - kesulitan membedakan antara } \\
\text { waktu kerja dan urusan pribadi }\end{array}$ \\
\hline & $\begin{array}{l}\text { - terhindar dari stres menghadapi } \\
\text { kemacetan }\end{array}$ & $\begin{array}{l}\text { - bekerja lebih lama dari waktu } \\
\text { standar }\end{array}$ \\
\hline & $\begin{array}{l}\text { - berkurangnya biaya } \\
\text { pengasuhan anak }\end{array}$ & \\
\hline & $\begin{array}{l}\text { - berpeluang lebih banyak } \\
\text { terlibat dalam kegiatan } \\
\text { komunitas } \\
\end{array}$ & \\
\hline $\begin{array}{c}\text { Pemberi } \\
\text { Kerja }\end{array}$ & $\begin{array}{l}\text { - menerima pegawai dari } \\
\text { berbagai daerah tanpa terikat }\end{array}$ & \\
\hline
\end{tabular}

The Indonesian Journal of Development Planning 


\begin{tabular}{|c|c|c|}
\hline Kategori & Manfaat/Kelebihan/Keunggulan & Kelemahan/Kekurangan/Tantangan \\
\hline & pertimbangan geografis & \\
\cline { 2 - 4 } Masyarakat & meningkatnya citra perusahaan & \\
\hline & berpeluang menciptakan bisnis \\
baru & - $\begin{array}{l}\text { terciptanya geger budaya (cultural } \\
\text { schock) berupa kesan menjadi } \\
\text { pengangguran, dan perubahan } \\
\text { kebiasaan keluarga, tetangga dan } \\
\text { komunitas yang belum siap. }\end{array}$ \\
\cline { 2 - 3 } & $\begin{array}{l}\text { peluang kerja lebih besar bagi } \\
\text { disabilitas, ibu yang sedang } \\
\text { mengasuh balita dan lanjut usia }\end{array}$ & \\
\cline { 2 - 3 } & - $\begin{array}{l}\text { meningkatnya keamanan jalan } \\
\text { raya }\end{array}$ & \\
\hline
\end{tabular}

Sumber: Mungkasa, Oswar (2020)

Secara khusus bekerja jarak jauh bukan hanya sekedar isu manajemen kantor, namun juga merambah lingkungan hidup, sosial, transportasi bahkan perkembangan sebuah kota. Tidak mengherankan bahwa bekerja jarak jauh mendapat lebih banyak perhatian pada bidang transportasi, kebijakan publik, dan komunitas bisnis, dengan alasan berpotensi sebagai strategi pengelolaan bangkitan lalulintas (Travel Demand Management/TDM) untuk mengatasi kemacetan dan peningkatan kualitas udara.

Pada awal 1990an, perencana transportasi memandang bekerja jarak jauh sebagai sebuah strategi manajemen permintaan perjalanan (Transportation Demand Management/TDM). Sebagai tambahan, bekerja jarak jauh menjadi bagian dari upaya memenuhi Undang-Undang Udara Bersih AS (Clean Air Act). The Clean Air Act Amendments (1990) yang mewajibkan negara memasukkan program pengurangan perjalanan ke tempat kerja dalam rencana pelaksanaannya. Namun, sejumlah pertanyaan masih menggantung terkait dampak bekerja jarak jauh terhadap perjalanan. Dampaknya kompleks, dan tidak selamanya bermanfaat (Salomon, 1985).

Meskipun begitu, berbagai penelitian telah menyimpulkan bahwa bekerja jarak jauh mengarah pada pengurangan perjalanan, khususnya pada jam puncak, dan pengurangan emisi nyata (Saxena dan Mokhtarian, 1997).

Pada tahun 1991, the Intermodal Surface Transportation Efficiency Act (ISTEA) memberi keleluasaan lebih besar bagi negara bagian dan pemerintah lokal untuk memenuhi kewajiban ini melalui ukuran permintaan perjalanan (TDMs), seperti bekerja jarak jauh, yang menjadi layak didanai melalui the Congestion Mitigation and Air Quality (CMAQ) Program, selain juga melalui the Surface Transportation Program (STP) (Department of Transportation USA, 1997).

Analisis Keruangan (spatial analysis) dari dampak bekerja jarak jauh terhadap pola perjalanan menjadi penting dikaji dampaknya terhadap energi, kualitas udara, dan guna lahan (Pendyala, Goulias, dan Kitamura, 1991). Pola perjalanan perorangan menjadi penentu utama struktur ruang perkotaan dan guna lahan. Perubahan preferensi keruangan dan perilaku perjalanan menyumbang perubahan struktur ruang kota (Horton dan Reynolds, 1971).

Dampak tidak langsung bekerja jarak jauh yang juga menarik perhatian adalah perpindahan tempat tinggal misalnya berupa berpindah tempat tinggal ke lokasi lebih jauh 
dengan pertimbangan tidak perlu lagi melakukan perjalanan setiap hari ke tempat kerja. Akibatnya, terdapat potensi bahwa bekerja jarak jauh mendorong fenomena rebakan kota (urban sprawl) (Lund dan Mokhtarian, 1994; Nilles, 1991). Segi positifnya, bekerja jarak jauh menjadi kesempatan baru bagi pengembangan kawasan pinggiran dengan menarik pemukim baru (Grimes, 2000; Simpson dkk., 2003).

Menariknya, pelaksanaan bekerja jarak jauh tidak membutuhkan penambahan rencana dalam Rencana Tata Ruang, merancangnya hanya membutuhkan waktu singkat dan mudah melaksanakannya dengan bantuan teknologi maju yang tidak perlu mahal (Mungkasa, 2020).

\subsection{Faktor Penentu dan Pendorong Kesuksesan}

Keberlangsungan bekerja dari rumah banyak tergantung pada berbagai faktor penentu dan pendorong. Beberapa hasil penelitian menunjukkan kesimpulan yang mirip bahkan sama. Sepertinya penelitian Higa dan Wijayanayake (1998) di Jepang dapat mewakili kesimpulan berbagai penelitian yang ada, khususnya terkait kota metropolitan, yang menunjukkan bahwa faktor penentu keberhasilan terhadap diterapkannya skema bekerja dari rumah adalah

(i) Waktu perjalanan. Lamanya waktu perjalanan mendorong perusahaan mendirikan kantor satelit bagi para pekerjanya

(ii) Harga rumah. Harga rumah di pusat kota sangat mahal dibanding pinggiran kota, sehingga perusahaan lebih memilih menyiapkan kantor satelit bagi pekerja.

(iii) Jenis pekerjaan. Jenis pekerjaan seperti pemasaran dan penyelidikan selalu bekerja berpindah-pindah tanpa melihat ukuran perusahaan

(iv) Ukuran perusahaan. Bagi perusahaan kecil menyiapkan kantor satelit jauh lebih mahal sehingga lebih memilih skema bekerja di rumah.

(v) Budaya organisasi. Budaya bekerja dalam kelompok dan selalu bertatap muka termasuk kebiasaan berkumpul di luar jam kantor menjadi penghalang bekerja dari rumah, dan sebagai alternatifnya adalah bekerja di kantor satelit.

(vi) Ukuran rumah. Rumah di Jepang relatif kecil, dan sulit menyediakan ruang khusus untuk bekerja. Bekerja di rumah menjadi sulit diterapkan.

Selain faktor penentu, perkembangan konsep bekerja dari rumah pada beberapa negara maju ditunjang oleh beberapa faktor, yaitu

(i) dukungan penuh pemerintah terutama dalam bentuk perbaikan regulasi;

(ii) tersedianya kajian awal yang dilanjutkan dengan uji coba dalam skala kecil;

(iii) pembentukan forum kolaborasi beranggotakan para pemangku kepentingan terkait, baik pemerintah maupun non pemerintah, untuk menyelenggarakan forum pertemuan berkala dalam rangka pelaksanaan Rencana Aksi Nasional;

(iv) pengembangan Rencana Aksi Nasional yang menggambarkan visi, misi, kebijakan dan strategi, peta jalan dan rencana aksi;

(v) penetapan jenis pekerjaan yang sesuai;

(vi) pemilihan tipe pekerja yang cocok;

(vii) penetapan standar kinerja dengan mengacu pada kesuksesan atau praktik unggulan (best practices) negara lain; 
(viii) pemberian insentif atau pemotongan pajak pada perusahaan yang mendorong implementasi bekerja jarak jauh di lingkungan kerjanya;

(ix) komitmen penuh dari perusahaan/institusi/organisasi diantaranya berupa penyediaan perangkat keras di rumah (Budhiekusuma, Hadi dan Winarno, 2017).

Sementara Overmyer (2011) menyimpulkan dari hasil penelitiannya terhadap penerapan bekerja jarak jauh pada 4 (empat) institusi pemerintah di Amerika Serikat bahwa kunci kesuksesan berdasar pada (i) komitmen pimpinan teras; (ii) kesamaan pandangan diantara para pimpinan; (iii) penyusunan kebijakan yang mewadahi harapan, peran dan tanggungjawab para pihak, serta misi organisasi; (iv) pelatihan pimpinan dan pegawai; (v) pemetaan kelayakan pegawai; (vi) inisiatif internal menyikapi perubahan; (vii) pengelolaan kinerja yang dapat terukur, mudah dipahami, dapat dicapai, dan mendukung tujuan institusi; (viii) komunikasi antara atasan, pegawai dan tim kerja tetap sama mudahnya seperti ketika bekerja di kantor; (ix) pendokumentasian perjanjian, dan panduan yang mudah dijangkau; (x) perlindungan terhadap keamanan data dan informasi; (xi) memperkecil biaya; (xii) kemudahan proses pendaftaran;

\section{Bekerja dari Rumah: Sebelum dan Saat Pandemi Covid-19}

Pada awal diterapkannya konsep bekerja jarak jauh, banyak pihak yang berharap banyak terhadap perkembangannya. Namun dengan berjalannya waktu ternyata pertumbuhannya tidak secepat yang diharapkan.

Berdasar pengalaman dari penerapan di berbagai negara, banyak faktor yang mempengaruhi kesuksesannya. Seperti di Jepang, ternyata perusahaan Jepang banyak yang menolak dengan pertimbangan budaya kerja yang mengedepankan bekerja selalu bertatap muka langsung. Selain itu, tidak semua jenis dan bidang pekerjaan dapat menerapkan konsep ini.

Konsep bekerja jarak jauh mulai mendapat perhatian banyak pihak pada akhir abad 20, menyertai kemunculan teknologi komunikasi dan komputer pribadi. Amerika serikat sebagai lokasi awal konsep bekerja jarak jauh, baru memulai program ujicoba di berbagai lokasi pada tahun 1990-an yang menjangkau banyak negara bagian, pemerintah daerah, dan perusahaan (Asgari, 2015).

Di Amerika Serikat barulah setelah tahun 1995 terjadi peningkatan pekerja jarak jauh (telecommuter) dari 8,5\% menjadi 11\% di tahun 1997 (Force, 2000). Bekerja jarak jauh mulai mendapat perhatian luas di Amerika Serikat sejak awal tahun 2000 dan berkembang cepat. Berdasar data Biro Pusat Statistik Amerika Serikat, jumlah pekerja jarak jauh di Amerika Serikat berkembang terus dari 18,7\% (2004) menjadi 23,3\% (2014) (Ohio,2015).

Penelitian tahun 2001 oleh International Telework Association and Council (ITAC) menunjukkan pekerja jarak jauh di AS mencapai satu banding lima pekerja konvensional. The United States Bureau of Transportation Statistics pada tahun 2006 menunjukkan 30 persen tenaga kerja AS bekerja di rumah setidaknya sekali seminggu (Mello, 2007). Walaupun demikian, angka pekerja yang bekerja jarak jauh regular dan lebih dari sekali seminggu masih jauh lebih kecil. Menurut Global Workplace Analytics and Telework Research Networks, bekerja jarak jauh reguler bertambah 79,7 persen antara 2005 sampai 2012 dan dengan kecepatan yang sama diperkirakan pekerja jarak jauh reguler akan mencapai 3,9 juta pada tahun 2016, mencerminkan pertambahan 21 persen dari tahun 2012 yang baru mencapai 
3,22 juta pekerja. Jika termasuk pekerja mandiri, pekerja non tradisional lapangan (misal konstruksi), perusahaan dengan seluruh pekerjanya bekerja jarak jauh, dan pekerja jarak jauh hanya 1 (satu) hari per minggu, maka jumlah pekerja jarak jauh akan menjadi sekitar 30 persen dari seluruh tenaga kerja Amerika Serikat (Ohio, 2015).

U.S. Bureau of Labor Statistics (2019) melaporkan bahwa selama periode 2017-2018, sekitar 28,8 persen pekerja yang berpotensi bekerja jarak jauh tapi hanya 24,8 persen dari total pekerja yang menjadi pekerja jarak jauh. Usia pekerja antara $35-44$ tahun yang terlihat paling banyak menjadi pekerja jarak jauh. Semakin bertambah usia semakin cenderung bekerja dari rumah.

Sementara semakin tinggi tingkat pendidikan semakin besar proporsi yang menjadi pekerja jarak jauh. Sekitar 46,5 persen dari pekerja dengan tingkat pendidikan sarjana menjadi pekerja jarak jauh. Pekerja yang mempunyai anak usia sekolah cenderung memilih bekerja dari rumah. Jenis pekerjaan manajemen, bisnis dan keuangan yang paling banyak memilih bekerja jarak jauh.

Menariknya di Amerika Serikat, ternyata tidak terlihat perbedaan besar proporsi antara pekerja jarak jauh pemerintah maupun pegawai non-pemerintah. Pegawai pemerintah lokal terlihat tidak terlalu berminat bekerja dari rumah. Sementara pegawai non-pemerintah yang bekerja di lembaga nirlaba lebih banyak yang tertarik bekerja di luar kantor dibanding pegawai perusahaan swasta.

Dalam periode tahun 2014-2018, pertambahan pegawai bekerja dari rumah sangat nyata, terutama jika dibandingkan dengan penurunan penggunaan moda transportasi mobil pribadi, kendaraan bersama (carpooled), berjalan kaki, transportasi publik. Sepertinya bekerja dari rumah mendorong penurunan penglaju secara nyata.

Beberapa tahun terakhir terjadi perkembangan yang tak terduga. Menurut Gallup poll, sekitar 43\% pekerja di Amerika bekerja di luar kantor, dan sekitar 31\% diantaranya atau sekitar 12\% dari seluruh pekerja di Amerika bekerja setidaknya 4-5 hari seminggu di luar kantor. Kondisi ini didukung oleh maraknya pekerja lepas (freelance) yang menjangkau separuh dari jumlah pekerja muda (milenial).

Walaupun bekerja jarak jauh dan bekerja leluasa telah menjadi populer, namun dalam kenyataannya pertambahan perusahaan di Amerika Serikat yang menawarkan skema ini hanya sekitar 4-5 persen dalam satu dekade terakhir (Landrum, 2015). Sejalan dengan itu, walaupun terkesan menguntungkan sebagai alternatif cara bekerja namun faktanya, Grobler and De Bruin (2011) mencatat misalnya hanya sedikit perusahaan di Afrika Selatan yang pegawainya memanfaatkan pilihan bekerja luar kantor. Pemanfaatan skema ini oleh pegawai tidak hanya dipengaruhi oleh preferensi mereka tetapi juga oleh persepsi pimpinan (Bianchi dan Milke 2010; Cooke 2005; Downes dan Koekemoer 2011).

Pada tahun 2015, jumlah pekerja jarak jauh di Eropa, istilah yang dipergunakan adalah telework, bervariasi antarnegara. Negara dengan proporsi pekerja jarak jauh terbesar adalah Denmark yang mencapai 36 persen, sementara yang terkecil adalah Itali sebesar 5 persen. Negara dengan proporsi pekerja jarak jauh di atas 10 persen cukup banyak yaitu Swedia, Belanda, Luksemburg, Perancis, Belgia, dan Finlandia. Sementara negara dengan proporsi pekerja jarak jauh dibawah 5 persen adalah Hongaria, Slowakia, Chech, Polandia, 
Portugal, Yunani. Sepertinya negara yang relatif kurang makmur cenderung kecil jumlah pekerja jarak jauhnya (Eurofound, 2020).

Tabel 2. Proporsi Pekerja dari Rumah Berbagai Negara

\begin{tabular}{|l|c|c|l|}
\hline Negara & $\begin{array}{c}\text { Proporsi } \\
(\%)\end{array}$ & Tahun & \multicolumn{1}{|c|}{ Sumber } \\
\hline Argentina & 2 & 2011 & $\begin{array}{l}\text { National Survey on Information and Communication } \\
\text { Technology }\end{array}$ \\
\hline Belgia & 23 & 2011 & Belgium Labour Force Survey \\
\hline Finlandia & 28 & 2013 & Finnish Working Life Barometer \\
\hline Perancis & 12 & 2004 & DARES \\
\hline Jerman & 12 & 2014 & Mikrozensus \\
\hline Hongaria & 1 & 2014 & Hungarian Labor Force Survey \\
\hline India & 19 & 2015 & \\
\hline Itali & 5 & 2013 & Smart Working Observatory of the Polytechnic \\
& 16 & 2014 & Teleworking Population Research \\
\hline Jepang & 15 & 2014 & Statistics Netherlands and TNO \\
\hline Belanda & 7 & 2011 & National Working Conditions Survey \\
\hline Spanyol & 32 & 2012 & Statistics Sweden \\
\hline Swedia & 4 & 2015 & Labor Force Survey-Office for National Statistics \\
\hline Inggris & 20 & 2012 & General Social Survey (GSS) \\
\hline AS & \multicolumn{2}{|l}{} \\
\hline
\end{tabular}

Sumber; Messenger dkk (2017)

Di Jepang sebagai salah satu negara maju, bahkan bekerja jarak jauh baru mulai menjadi bagian dari bisnis setelah tahun 1995, sementara pemerintah Jepang sendiri baru memulai menerapkan secara resmi pada tahun 1998. Data terbaru berdasar survei oleh RIETI, hanya kurang dari 105 perusahaan Jepang yang menerapkan bekerja jarak jauh pada tahun 2019 (Morikawa, 2020).

Namun konsep yang diterapkan bukan bekerja dari rumah (workingfrom home), tetapi bekerja dari kantor satelit yang berada tidak jauh dari lokasi kediaman. Hal ini terutama disebabkan oleh hambatan budaya organisasi perusahaan Jepang. Pegawai selalu berinteraksi langsung, bertatap muka baik di kantor maupun setelah jam kantor. Selain itu, dalam budaya Jepang rumah menjadi kewenangan pengelolaan istri, sehingga keberadaan suami bekerja di rumah akan mengganggu kenyamanan istri. Ditambah pula ukuran rumah Jepang relatif kecil (Higa dan Wijayanayake, 1998).

Di Indonesia sendiri tidak terdapat data yang pasti tentang bekerja jarak jauh. Namun, sejak awal tahun 2020 Kementerian Perencanaan Pembangunan Nasional/Bappenas telah mencanangkan uji coba bekerja jarak jauh dengan nama Flexi Work. Sampai saat ini belum terdapat laporan pelaksanaan uji coba tersebut, sehingga evaluasi terhadap uji coba tersebut belum dapat dilakukan. Walaupun demikian, pelaksanaan flexi work Bappenas berjalan lancar, dan hadirnya pandemi Covid-19 menjadi momentum pengarusutamaan hasil uji coba bekerja jarak jauh di Bappenas. 
Penerapan bekerja dari rumah sebagian besar bersifat sukarela sesuai kebutuhan. Namun, keberadaan pandemik Covid-19 menjadikan bekerja dari rumah adalah keharusan. Tentu saja terdapat perbedaan besar. Beberapa organisasi/perusahaan memang sudah siap melaksanakan bahkan telah melaksanakan skema bekerja dari rumah baik sebagian maupun seluruh pegawai. Sementara bagi organisasi/perusahaan yang tidak siap, penerapan bekerja dari rumah cukup merepotkan pada awalnya, walaupun dengan berjalannya waktu sedikit demi sedikit para pegawai dapat menyesuaikan diri.

Beberapa perusahaan besar berbasis di Amerika Serikat telah menerapkan bekerja di rumah sejak awal merebaknya Covid-19, diantaranya adalah Microsoft, Amazon, Twitter, Google, Facebook, LinkedIn, dan Zoom.

Sementara beberapa negara yang terdampak nyata oleh Covid-19 seperti Cina melaksanakan sepenuhnya bekerja dari rumah walaupun kemudian banyak organisasi/perusahaan belum siap melaksanakan. Namun, kendala utamanya ternyata adalah geger budaya berupa ketidakpercayaan para pimpinan terhadap pegawai. Prosedur yang diterapkan membuat pegawai tidak nyaman disebabkan permintaan untuk melaporkan perkembangan pekerjaan setiap waktu berikut foto keberadaan pegawai.

Di Jepang, pemerintah menyediakan subsidi kepada perusahaan kecil dan menengah untuk membantu biaya memperkenalkan dan menerapkan sistem bekerja dari rumah pada masing-masing perusahaan. Serupa dengan cina, hambatan utamanya adalah hambatan budaya. Bagi masyarakat Jepang, bekerja adalah 'berangkat ke kantor' dan bukan 'berdiam di rumah'. Selain itu, kebiasaan pegawai Jepang bekerja lembur setiap hari akan berubah drastik dan akan lebih banyak waktu buat keluarga.

Kondisi serupa terjadi di Korea Selatan. Hambatan utama bekerja dari rumah adalah adanya budaya 'bekerja dalam kondisi sakit adalah suatu kebajikan'. Sebagai akibatnya hanya pegawai yang hamil, atau memiliki anak balita dan masih sekolah yang diperkenankan bekerja dari rumah. Sehingga anjuran dari pemerintah Kota Seoul untuk berhenti bekerja di kantor dan beralih bekerja dari rumah dalam waktu setidaknya dua minggu tidak memperoleh banyak tanggapan (Hess, 2020)

Menarik kemudian mengetahui pandangan para pegawai yang tiba-tiba harus menjalani skema bekerja dari rumah. Salah satu penelitian yang dilakukan oleh Okta (accessmanagement company) di Inggris terhadap 6.000 pekerja di seluruh Eropa menunjukkan beberapa hal menarik. Pertama, sekitar 75 persen pegawai tetap menginginkan bekerja dari rumah. Kedua, hanya sekitar 17 persen yang menginginkan bekerja dari rumah sepenuhnya. Selebihnya menginginkan bekerja dari rumah paruh waktu.

Hasil penelitian juga menunjukkan para responden melaporkan produktivitas meningkat karena keleluasaan waktu dan berkurangnya gangguan. Sementara kekhawatiran bahwa tanpa pengawasan yang memadai dapat menurunkan produktivitas ternyata tidak terbukti. Pesan yang tertangkap dari hasil survei Okta adalah pegawai menginginkan keleluasaan (fleksibilitas) dalam memilih waktu bekerja dari rumah sesuai dengan kebutuhan (Leprince-Ringuet, 2020)

Sebuah penelitian lain oleh perusahaan riset Valoir, yang dipublikasikan pada Mei 2020, menunjukkan bahwa sekitar 40 persen pegawai yang bekerja dari rumah pada era pandemi menginginkan bekerja penuh dari rumah. Hasil penting lainnya adalah 
(i) Produktivitas berkurang sangat kecil, hanya berkisar 1 sampai 3 persen. Keberadaan anak kecil di rumah hanya mengurangi produktivitas sekitar 2 persen, dan ternyata bekerja sendiri di rumah tanpa keluarga bahkan mengurangi produktivitas lebih besar sekitar 3 persen.

(ii) Waktu kerja harian rata-rata sekitar lebih dari 9 jam, dimulai dari jam 8 pagi sampai jam 6 sore. Ternyata waktu kerja dari rumah relatif sama dengan waktu kerja kantor dan hanya sekitar 10 persen yang bekerja di luar jadwal normal.

(iii) Gangguan utama adalah media sosial. Sekitar sepertiga responden melaporkan menghabiskan waktunya hampir dua jam sehari membaca informasi dari media sosial.

(iv) Pegawai memperoleh dukungan penuh dari kantor. Sekitar 75 persen responden menyatakan memperoleh dukungan penuh dari kantor dan hanya sekitar 5 persen yang menyatakan sebaliknya.

(v) Kekhawatiran utama adalah keberlangsungan pekerjaan. Hal ini disampaikan oleh sepertiga dari responden yang mengkhawatirkan kelangsungan hidup perusahaan maupun pekerjaan (Afshar, 2020).

\section{Pembelajaran Penerapan Bekerja Jarak Jauh di Mancanegara pada Era Pandemi Covid-19}

\subsection{Komitmen, Dukungan dan Regulasi Pemerintah}

Pada beberapa tahun terakhir, di Amerika Serikat, bekerja jarak jauh dilihat sebagai perangkat pengelolaan strategis ketika terjadi kondisi darurat atau gangguan terhadap pelaksanaan pekerjaan seperti cuaca ekstrim atau bentuk kedaruratan lainnya.

Minat Kongres memperluas penerapan bekerja jarak jauh pada institusi pemerintah dimulai dengan sungguh-sungguh melalui Transportation and Related Agencies Appropriations Act of 2001 (Public Law 106-346), yang mensyaratkan setiap institusi pemerintah menyusun kebijakan yang memungkinkan pegawai bekerja jarak jauh tanpa mengurangi kinerjanya. Undang-Undang ini mensyaratkan Office of Personnel Management (OPM) untuk memastikan bahwa bekerja jarak jauh telah mulai dilaksanakan oleh setidaknya 25 persen dari pegawai pemerintah pusat yang layak dalam enam bulan sejak diberlakukannya aturan ini, dan tambahan 25 persen pegawai yang layak pada tahun berikutnya.

Menindaklanjuti hal ini, kemudian OPM menyelenggarakan survei awal pada tahun 2000 untuk mengetahui kinerja bekerja jarak jauh di kantor pemerintah federal. Selanjutnya sejak tahun 2002 telah diterbitkan laporan berkala.

Sebagai kelanjutan undang-undang tersebut, diterbitkan beberapa regulasi lagi (selengkapnya lihat Tabel 2), yang memberi mandat kepada institusi pemerintah agar meningkatkan partisipasi pegawai dalam skema bekerja jarak jauh. Termasuk memerintahkan agar ditetapkan koordinator program pada setiap kantor dan menyampaikan laporan berkala ke Kongres. Kongres menahan alokasi sejumlah tertentu dana institusi pemerintah sampai seluruh pegawai yang layak telah bergabung dengan program bekerja jarak jauh. 
Tabel 3. Rangkaian Peraturan terkait Bekerja Jarak Jauh di Amerika Serikat

\begin{tabular}{|c|c|}
\hline Tahun & Regulasi \\
\hline 1990 & $\begin{array}{l}\text { Treasury, Postal Service and General Government Appropriations } \\
\text { Act, 1991 Public Law 101-509, \$624: } \\
\text { Bagian ini membolehkan institusi pemerintah berpartisipasi dalam } \\
\text { kegiatan Federal Flexiplace Project untuk memanfaatkan dana yang } \\
\text { diperuntukkan bagi pembayaran pemasangan telepon, pembelian } \\
\text { perangkat, dan pembayaran biaya telepon bulanan di rumah pegawai. } \\
\text { Pertama kalinya Kongres menyediakan dana bagi penyelenggaraan } \\
\text { "flexiplace" (istilah lain bekerja dari rumah). }\end{array}$ \\
\hline 1992 & $\begin{array}{l}\text { Treasury, Postal Service and General Government Appropriations } \\
\text { Act, } 1991 \text { Public Law 102-393, \$625 (halaman 43) }\end{array}$ \\
\hline 1993 & $\begin{array}{l}\text { Treasury, Postal Service and General Government Appropriations } \\
\text { Act, Public Law 103-123, } \$ 623 \text { (halaman } 40 \text { ) }\end{array}$ \\
\hline 1994 & $\begin{array}{l}\text { Treasury, Postal Service and General Government Appropriations Act, Public } \\
\text { Law 103-329, \$625 (halaman 41) }\end{array}$ \\
\hline 1996 & $\begin{array}{l}\text { Treasury, Postal Service, and General Government Appropriations } \\
\text { Act, Public Law 104-52, \$620 (halaman 35) } \\
\text { Omnibus Consolidated Appropriations Act, 1997, Public Law 104-208 } \\
\text { \$407 (halaman 338) } \\
\text { Bagian ini mengijinkan GSA untuk membangun Pusat Bekerja Jarak Jauh. } \\
\text { Selain juga mengijinkan GSA untuk menyusun panduan, pendampingan, } \\
\text { dan pengawasan terkait perencanaan, pembangunan dan pengelolaan } \\
\text { pengaturan alternatif tempat kerja }\end{array}$ \\
\hline 1999 & $\begin{array}{l}\text { Omnibus Consolidated and Emergency Supplemental Appropriations Act, Public } \\
\text { Law 105-277, } \$ 630 \text { (halaman 523) } \\
\text { Bagian ini menyisihkan pendanaan bagi institusi pemerintah terkait untuk } \\
\text { menjalankan program bekerja jarak jauh (flexiplace work telecommuting } \\
\text { program).. Program ini didefinisikan sebagai program yang } \\
\text { memungkinkan pegawai institusi pemerintah menjalankan sebagian atau } \\
\text { seluruh kegiatannya pada pusat bekerja jarak jauh (flexiplace work } \\
\text { telecommuting center). }\end{array}$ \\
\hline 2000 & $\begin{array}{l}\text { Department of Transportation and Related Agencies Appropriations Act, Public } \\
\text { Law 106-346, } \$ 359 \text { (halaman 38) } \\
\text { Bagian ini memerintahkan setiap institusi pemerintah menetapkan } \\
\text { kebijakan bekerja jarak jauh yang memungkinkan pegawai bekerja jarak } \\
\text { jauh sepanjang kinerjanya tidak terganggu. }\end{array}$ \\
\hline 2002 & $\begin{array}{l}\text { Treasury, Postal Service, and General Government Appropriations Act, Public } \\
\text { Law 107-67, \$638 (halaman 41) } \\
\text { Bagian ini memerinthakan institusi pemerintah terkait untuk melapor ke } \\
\text { Office of Personnel Management (OPM) terkait upaya pelaksanaan program } \\
\text { bekerja jarak jauh. }\end{array}$ \\
\hline 2003 & $\begin{array}{l}\text { Consolidated Appropriations Resolution, Public Law 108-7, \$623 (halaman } \\
93 \text { 93 } \\
\text { Bagian ini memberikan hibah kepada the Departments of Commerce, Justice, } \\
\text { and State, the Judiciary, dan the Small Business Administration untuk } \\
\text { melaksanakan program bekerja jarak jauh. Diperlukan juga laporan } 6 \\
\text { bulanan dan penunjukan koordinator program. } \\
\text { Telecommuting and other alternative workplace arrangements, } \\
\text { Public Law 107-217, \$587 (halaman 53-55) }\end{array}$ \\
\hline
\end{tabular}

The Indonesian Journal of Development Planning 


\begin{tabular}{|c|c|}
\hline & $\begin{array}{l}\text { Bagian ini mengamanatkan pengembangan tempat kerja alternative dan } \\
\text { memerintahkan GSA menyediakan panduan, pendampingan, dan } \\
\text { pengawasan terhadap institusi pemerintah terkait perencanaan, } \\
\text { pembangunan dan pengelolaan alternative tempat kerja. Pengaturan } \\
\text { alternatif tempat kerja mencakup hotel, kantor virtual, pusat bekerja jarak } \\
\text { jauh, hot desking, dan tempat kerja yang menyebar. }\end{array}$ \\
\hline 2004 & $\begin{array}{lllllll}\begin{array}{l}\text { Consolidated } \\
\text { (halaman 97) }\end{array} & \text { Appropriations } & \text { Act, Public Law } & \text { 108-199, } & \$ 627 \\
\end{array}$ \\
\hline 2005 & $\begin{array}{l}\text { Consolidated Appropriations Act, Public Law 108-447 } \$ 622 \text { (halaman } \\
111 \text { ) }\end{array}$ \\
\hline 2010 & $\begin{array}{l}\text { Telework Enhancement Act of } 2010 \text {, Public Law 111-292 (external link) } \\
\text { Undang-Undang memerintahkan setiap institusi pemerintah menetapkan } \\
\text { dan melaksanakan kebijakan yang mengijinkan pegawai bekerja jarak } \\
\text { jauh. Selain itu, memerintahkan setiap institusi menunjuk petugas } \\
\text { pengelola bekerja jarak jauh, mensyaratkan pegawai mengikuti pelatihan, } \\
\text { dan menandatangani perjanjian tertulis, memerintahkan institusi } \\
\text { menggabungkan bekerja jarak jauh ke dalam rencana kerja , dan } \\
\text { mengembangkan pedoman bekerjasama dengan OPM untuk memenuhi } \\
\text { kebutuhan laporan tahunan. }\end{array}$ \\
\hline
\end{tabular}

Sumber: diolah dari telework.gov

Keberadaan The Telework Enhancement Act of 2010 merupakan kunci penting yang menjadi pendorong utama pemerintah Federal Amerika Serikat dalam menjalankan program Bekerja Jarak Jauh. Penandatanganan undang-undang ini merupakan puncak pencapaian legislatif dalam memajukan program pemerintah Federal.

Secara umum, undang-undang tersebut mencakup beberapa hal penting, diantaranya adalah

(i) memerintahkan setiap institusi pemerintah Federal menyiapkan kebijakan yang memungkinkan pegawai menjalankan skema bekerja jarak jauh atau bekerja dari rumah.

(ii) menyiapkan definisi resmi terkait bekerja jarak jauh dan menetapkan kelayakan pegawai. Tidak semua pegawai dapat bergabung bekerja jarak jauh, baik alasan jenis pekerjaan maupun tingkat kedisiplinan pegawai.

(iii) mensyaratkan perjanjian tertulis antara pegawai dan atasan. Perjanjian ini setidaknya mencakup target kinerja yang harus terpenuhi.

(iv) mensyaratkan pimpinan kantor memasukkan bekerja jarak jauh dalam rencana kerja

(v) menetapkan pejabat pengelola bekerja jarak jauh

(vi) mensyaratkan pimpinan dan pegawai mengikuti pelatihan bagi calon pekerja jarak jauh

(vii) menguraikan tanggungjawab dan harapan sebagai masukan panduan kebijakan dan pelaporan

(viii) mensyaratkan bermitra dengan OPM untuk menyiapkan data dan laporan.

(ix) mengembangkan situs internet

(x) menyediakan kerangka kerja pengembangan teknologi dan optimalisasi pemanfaatan bekerja jarak jauh

(xi) mendukung institusi pemerintah untuk mencapai tujuan

(xii) meningkatkan keseimbangan kerja-kehidupan pegawai (Overmyer, 2012). 
Selain itu, setiap institusi terkait mempunyai peran dan tanggungjawab masingmasing sesuai dengan penetapannya dalam ketentuan yang telah disiapkan. Pemerintah Federal pun menyiapkan panduan Bekerja Jarak Jauh pada tahun 2011, yang setidaknya memberi arahan terkait (i) jadwal kerja, gaji, dan hak cuti; (ii) pengelolaan kinerja; (iii) tempat kerja; (iv) bekerja jarak jauh di luar negeri; (v) akomodasi; (vi) bekerja jarak jauh kondisi darurat; (vii) penerimaan pegawai; dan (viii) keamanan data (telework.gov, 2020).

\subsection{Kebijakan Organisasi/Perusahaan}

Pada saat pandemik Covid-19 yang mengharuskan bekerja jarak jauh untuk mengurangi pergerakan penduduk, ternyata secara umum regulasi yang mendukung sudah cukup memadai. Namun masih dibutuhkan aturan perusahaan atau organisasi yang mempekerjakan pegawai jarak jauh.

Untuk itu, penyusunan kebijakan organisasi/perusahaan menjadi suatu keniscayaan. Berdasar pembelajaran pada beberapa perusahaan di Amerika Serikat, sejak dimulainya penerapan bekerja jarak jauh era pandemik Covid-19, penyusunan kebijakan perusahaan didasari oleh beberapa isu mendasar, yaitu:

(i) Kelayakan. Perusahaan perlu menentukan posisi yang layak untuk bekerja jarak jauh, dan secara jelas ditetapkan dalam kebijakan. Melalui analisis model jenis pekerjaan dan operasional kantor, perusahaan dapat menetapkan skema bekerja jarak jauh seluruh kantor yang mencakup jenis pekerjaan, posisi, bahkan pengaturan waktu yang tepat untuk bekerja jarak jauh (termasuk kemungkinan skema bergiliran)

Walaupun kemudian dapat terjadi tidak ada satupun pekerjaan yang dapat dilaksanakan di luar kantor. Namun sepanjang ditetapkan dengan jelas dalam kebijakan perusahaan maka hal ini tidak akan menjadi sumber pertanyaan di masa depan.

Namun dalam kondisi pandemik Covid-19 ketika kantor ditutup dan pegawai diarahkan bekerja dari rumah, terdapat kondisi pegawai tidak dapat melakukannya berdasar kondisi/alasan tertentu. Sebagai ilustrasi, ketika kemudian sekolah juga diliburkan dan membuat orang tua tidak dapat bekerja untuk menjaga sang anak.

Di Amerika Serikat, berdasar Families First Coronavirus Response Act ("FFCRA"), sejak 1 April 2020 pegawai yang tidak dapat bekerja atau tidak dapat bekerja jarak jauh karena alasan tertentu terkait pandemik Covid-19 (termasuk dalam daftar kelayakan FFCRA) akan memperoleh kompensasi dan dianggap cuti dengan gaji tetap dbayarkan.

(ii) ketersediaan. Jika perusahaan membolehkan bekerja jarak jauh, maka dalam kebijakan perusahaan perlu dinyatakan secara jelas bentuk pengaturannya termasuk jadwal, pengaturan kehadiran di kantor jika tidak bekerja di luar kantor, dukungan perusahaan atau pekerja menyiapkan perlengkapannya sendiri di rumah.

(iii) Pengaturan jadwal perlu disepakati sejak awal untuk menghindari kecemburuan dan perasaan diperlakukan tidak adil dari pegawai yang tetap bekerja di kantor atau sedang dapat giliran bekerja di kantor. Selain itu, perlu dipikirkan kompensasi bagi pekerja yang tidak mempunyai peluang bekerja di luar kantor.

(iv) kecepatan tanggapan. Keberadaan pegawai yang jauh dari pengamatan langsung pimpinan kadang memunculkan rasa kecurigaan atau kekhawatiran bahwa pegawai tidak melaksanakan tugasnya sesuai aturan. Untuk itu, kecepatan pegawai dalam menanggapi pertanyaan atau permintaan dari kantor maupun sesama pegawai akan membantu menghilangkan kekhawatiran tersebut. 


\section{Oswar Mungkasa}

Pengaturan kecepatan tanggapan tersebut secara tertulis, maupun bentuk perangkat komunikasi yang dipergunakan menjadi bagian penting dalam kebijakan perusahaan. Penetapan kebijakan yang jelas dapat menghindari terjadinya hubungan yang kurang harmonis diantara atasan dengan pegawai dan sesama pegawai.

(v) ukuran produktivitas. Salah satu faktor yang mendorong maraknya bekerja jarak jauh adalah hasil penelitian yang menunjukkan peningkatan produktivitas bekerja jarak jauh lebih baik dari bekerja konvensional. Namun keberadaan pegawai yang jauh dari pantauan langsung pimpinan membutuhkan pemilihan metode baru pengukuran produktivitas pegawai.

Terdapat banyak pilihan metode pengukuran mulai dari lamanya waktu pelaksanaan pekerjaan, jumlah masalah yang terselesaikan, sampai jumlah rekanan yang tertangani. Tentu saja metode pengukuran tidak sesederhana sekedar menghitung jumlah lamanya bekerja, tetapi lebih berfokus pada keluaran yang dihasilkan.

Walaupun demikian, pemantauan lamanya bekerja dan penyerahan laporan perkembangan pekerjaan tetap diperlukan. Absensi daring termasuk lokasinya dilakukan awal dan akhir dilengkapi dengan laporan harian. Beberapa perusahaan telah dilengkapi dengan aplikasi yang dapat mengakomodasi absensi, pelaporan, diskusi daring, berbagi informasi dan lainnya.

Pemantauan terhadap kemajuan pekerjaan dapat dilakukan secara daring dan berkala. Hal ini juga sebagai pengganti pertemuan tatap muka diantara pegawai yang sering terjadi di kantor.

(vi) Perangkat kantor. Bekerja jauh dari kantor membutuhkan perangkat pendukung mulai dari komputer jinjing atau komputer meja, telepon genggam, printer, dan lainnya. Keseluruhan perangkat tersebut perlu ditetapkan dalam kebijakan perusahaan terkait penanggungjawab penyediaannya. Bisa saja perangkat disediakan sendiri oleh pegawai. Bahkan beberapa perusahaan mensyaratkan ketersediaan internet dengan kapasitas dan kecepatan tertentu di rumah. Hal ini untuk memastikan komunikasi dapat berjalan lancar antara pegawai dan kantor. Sementara jika perusahaan menyediakan perangkat pendukung, sebaiknya tidak membebani atau mengurangi tunjangan pegawai.

(vii) dukungan teknis. Bersama dengan ketersediaan perangkat pendukung, maka perlu dipastikan tersedianya dukungan teknis yang dapat diberikan baik secara langsung maupun tidak langsung oleh perusahaan. Ini yang menjadi salah satu kendala utama pelaksanaan bekerja jarak jauh. Gangguan teknis terhadap perangkat pendukung perlu dipastikan dapat tertangani dengan baik melalui bantuan kantor atau dilakukan oleh pegawai sendiri.

(viii) pemberhentian pegawai. Pada beberapa perusahaan masih ditemui pimpinan yang kurang berkenan dengan skema bekerja jarak jauh. Sehingga pegawai yang bekerja jarak jauh perlu diberi perlindungan khusus untuk tidak diberhentikan karena alasan bekerja jarak jauh. Dengan demikian, terlihat bahwa komunikasi yang lancar menjadi suatu keniscayaan agar rentang kendali atasan tetap terjaga.

(ix) lingkungan fisik. Beberapa perusahaan memasyaratkan kondisi lingkungan rumah yang perlu dipenuhi agar diperbolehkan bekerja jarak jauh. Biasanya menyangkut isu kesehatan, keamanan bahkan juga kenyamanan bekerja.

Keamanan kerja menjadi perhatian utama perusahaan karena walaupun kecelakaan kerja terjadi di rumah, tetapi tetap menjadi tanggungjawab perusahaan. Di Amerika 
Serikat, berdasar the Occupational Safety and Health Administration (OSHA), perusahaan tetap bertanggungjawab memberikan kompensasi dan/atau perawatan terhadap kecelakaan kerja pegawai bekerja jarak jauh (Warren, 2020).

(x) ketersediaan data, dan upaya pengamanannya. Bekerja jarak jauh mengandalkan data virtual yang tersimpan rapi dalam sebuah kumpulan data yang biasa disebut BIG Data. Pemindahan data, baik dari rumah ke kantor dan sebaliknya maupun dari rumah ke rumah, melalui daring yang demikian intensif membuka peluang pihak luar dapat mencuri data tersebut. Sehingga upaya pengamanan data menjadi penting dan salah satu persyaratan skema bekerja dari rumah. Bahkan beberapa perusahaan secara khusus mengeluarkan aturan melarang memanfaatkan fasilitas wifi yang bisa diakses publik.

(xi) kerahasiaan mitra kerja. Isu kerahasiaan mitra kerja beriringan dengan isu keamanan data dan informasi. Menjaga kerahasiaan mitra kerja memang sangat sulit dilakukan dalam kondisi bekerja jarak jauh. Perusahaan mungkin menerapkan jenis pekerjaan tertentu yang tidak boleh dilakukan dalam skema bekerja jarak jauh (Bayern, 2020)

\subsection{Dampak terhadap Pembangunan Kota}

Setelah merebaknya Covid-19, dan berlakunya skema bekerja dari rumah, karakter bangkitan lalulintas kota menjadi berubah. Pertama, jumlah perjalanan menjadi berkurang dan waktu puncak juga dapat berubah karena salah satu karakter dari bekerja dari rumah adalah keleluasaan waktu kerja. Kedua, jumlah perjalanan menggunakan kendaraan pribadi dapat meningkat jika protokol Covid-19 tidak dijalankan secara disiplin pada transportasi publik. Ketiga, dalam jangka panjang perebakan kota (urban sprawl) dapat marak kembali karena faktor jarak rumah-kantor menjadi kurang penting lagi.

\subsection{Kelayakan Jenis Pekerjaan}

Dipahami bersama bahwa tidak semua jenis pekerjaan sesuai dilaksanakan dari rumah. Berdasar riset yang dilakukan oleh Virtual Vocation (2020) di Amerika Serikat, Amerika Utara dan Eropa diperoleh gambaran bahwa jenis pekerjaan yang paling banyak ditawarkan adalah pekerjaan menyangkut administrasi, teknologi informasi, desain, keuangan, pemasaran, sumberdaya manusia, manajemen proyek, dan menulis.

Dengan demikian, pemetaan kelayakan jenis pekerjaan yang dapat dilakukan di rumah pada masing-masing organisasi/institusi menjadi suatu keniscayaan.

\subsection{Dampak, Manfaat dan Hambatan}

Berbagai penelitian menunjukkan bahwa produktivitas bekerja dari rumah tidak berbeda dengan produktivitas bekerja konvensional. Namun, hanya sedikit pegawai yang menginginkan bekerja sepenuhnya dari rumah. Bersosialisasi masih menjadi suatu kebutuhan dasar manusia.

Selain itu, kualitas hubungan antara anggota keluarga menjadi lebih baik bahkan kekhawatiran terganggunya waktu kerja oleh kegiatan rumah tangga tidak menjadi kenyataan.

Dampak positif terhadap kondisi lingkungan hidup juga terwujud nyata salah satunya berupa menurunnya tingkat polusi udara. Pola hidup bersih dan sehat menjadi marak kembali. 
Walaupun awalnya ditengarai kendala ketersediaan perangkat teknologi yang memadai menjadi hambatan. Namun, kemudian di beberapa negara Asia ternyata isu budaya menjadi hambatan utama pelaksanaan bekerja dari rumah.

\subsection{Budaya Kerja dari Rumah}

Masih banyak yang tidak bisa membedakan antara bekerja dari rumah dan bekerja di rumah. Bekerja dari rumah merupakan bagian dari pemenuhan kewajiban sebagai seorang pegawai dalam memenuhi target pekerjaan. Jadi rumah hanya sebagai lokasi saja. Berbeda dengan bekerja di rumah yang dapat berarti tidak terkait dengan kewajiban melaksanakan tugas kantor.

Dengan demikian dalam menjalankan bekerja dari rumah, protokol dan suasana kantor tetap harus terpelihara. Sehingga beberapa hal tetap perlu dijaga seperti (i) jadwal kerja tetap diusahakan seperti jadwal kantor seperti biasanya; (ii) lokasi bekerja sebaiknya dibuat terpisah dari kegiatan domestik lainnya; (iii) pekerjaan domestik dan pekerjaan kantor dilaksanakan tidak dalam waktu yang bersamaan, tetapi dapat dibuat jadwal masing-masing; (iv) pakaian yang dikenakan juga sebaiknya bukan pakaian santai seperti kaos, atau daster.

\section{Antisipasi Tataran Baru (New Model) Bekerja Jarak Jauh di Indonesia}

Perjalanan konsep bekerja jarak jauh atau bekerja dari rumah telah lebih dari 50 tahun. Dimulai sebagai jawaban terhadap masalah kemacetan akibat perjalanan dari rumah ke kantor dan sebaliknya. Kemudian menjadi salah satu bagian dari upaya efisiensi biaya baik bagi perusahaan maupun pegawai. Bahkan belakangan menjadi jawaban terhadap kondisi kedaruratan ketika keberadaan di kantor menjadi terkendala. Merebaknya Covid-19 menjadi contoh gamblang.

Dengan demikian, bekerja jarak jauh dapat menjadi jawaban terhadap isu perkotaan maupun kondisi kedaruratan dalam jangka pendek, maupun panjang. Namun demikian, bekerja jarak jauh belum menjadi arus utama dalam kehidupan modern manusia.

Keberadaan pandemik Covid-19 ini yang mewajibkan sebagian besar pegawai di seluruh dunia bekerja dari rumah, kemudian dapat menjadi dorongan baru bagi perkembangan skema bekerja dari rumah. hal ini terbukti dari beberapa hasil penelitian di mancanegara terhadap persepsi pegawai tentang skema bekerja dari rumah pada era pandemik Covid-19, yang seluruhnya menunjukkan minat pegawai untuk mempertahankan skema bekerja dari rumah baik purna waktu maupun paruh waktu. Untuk itu, sepertinya skema bekerja dari rumah akan menjadi salah satu tatanan baru (new normal) dunia.

Agar kecenderungan ini dapat diantisipasi, maka dibutuhkan upaya pengarusutamaan konsep bekerja dari rumah secara sistematis. Beberapa tonggak pencapaian (benchmark) yang perlu ditetapkan adalah

\section{Tata Kelola, Rencana Aksi, dan Insentif}

\subsection{Sisi Tata Kelola (Governance)}

\section{a. Komitmen pemangku kepentingan}

Dasar utama pengarusutamaan bekerja dari rumah dimulai dengan adanya komitmen para pemangku kepentingan yang upayanya dimulai dari sisi pemerintah pusat. Komitmen ini didukung semua pihak, baik pemerintah, legislatif, swasta, maupun masyarakat. 


\section{b. Wadah Kolaborasi}

Komitmen ini dapat tercapai melalui kolaborasi para pemangku kepentingan. Untuk itu, sebagai langkah awal tentu dibutuhkan sebuah wadah bagi para pemangku kepentingan untuk saling berbagi, berdiskusi, bersepakat untuk berkomitmen.

Wadah ini kita sebut saja Forum Bekerja Jarak Jauh yang keanggotaannya bersifat terbuka, dan egaliter. Pengambilan keputusan dilakukan secara bersama dan mengedepankan 'win-win solution'.

Forum ini nantinya menghasilkan konsensus yang setidaknya mencakup kesamaan pandangan, dan kesepakatan tentang tujuan penerapan bekerja jarak jauh. Forum ini nantinya juga sekaligus berfungsi sebagai forum koordinasi, pemantauan dan evaluasi pelaksanaan skema bekerja dari rumah. wadah kolaborasi ini juga dapat dibentuk pada tingkat pemerintah kota/kabupaten

\section{c. Rencana Aksi Nasional Penerapan Bekerja dari Rumah}

Rencana Aksi Nasional Penerapan Bekerja dari Rumah merupakan perwujudan nyata dari komitmen pemangku kepentingan. Rencana aksi merupakan produk dari Forum Bekerja Jarak Jauh sebagai acuan pengarusutamaan konsep bekerja jarak jauh.

Materi Rencana Aksi mencakup tujuan, target, kebijakan-strategi-regulasi, peta jalan, dan rencana kegiatan.

\section{d. Regulasi Pendukung}

Sampai saat ini, tidak tersedia regulasi yang secara khusus mendukung skema bekerja jarak jauh khususnya dalam konteks jangka panjang. Beberapa aturan yang dikeluarkan selama pandemik Covid-19 telah mengatur bekerja jarak jauh yang bersifat sementara. Dibutuhkan regulasi yang dapat berupa undang-undang baru atau amandemen undangundang ketenagakerjaan yang telah ada beserta peraturan pendukungnya, yang dilengkapi kebijakan di masing-masing institusi pemerintah, organisasi maupun perusahaan.

Regulasi yang mengatur bekerja jarak jauh setidaknya mencakup materi (i) pembentukan forum pemangku kepentingan berikut bentuk organisasi, keanggotaan, peran dan tanggungjawab, serta keluaran utama; (ii) penetapan definisi bekerja jarak jauh; (iii) penyusunan Rencana Aksi Nasional; (iv) internalisasi bekerja jarak jauh dalam dokumen pembangunan baik nasional, maupun daerah; (v) pengaturan kelayakan keikutsertaan dalam skema bekerja jarak jauh; (vi) pengembangan basis data dan manajemen pengetahuan; (vii) penyediaan insentif dan disinsentif; (viii) pengembangan strategi komunikasi publik; (ix) pengembangan kapasitas sumberdaya manusia dan teknologi; (x) pemantauan dan evaluasi.

\subsection{Internalisasi dalam Dokumen Pemerintah}

Agar konsep bekerja dari rumah dapat terlaksana, maka dibutuhkan upaya internalisasi Rencana Aksi Nasional/Daerah ke dalam dokumen pembangunan baik nasional maupun daerah. Secara eksplisit kebijakan, target, strategi dan kegiatan terkait bekerja dari rumah perlu tercantum dalam dokumen seperti RPJMN/D, Renstra K/L atau OPD, bahkan rencana tahunan.

\subsection{Pedoman Pelaksanaan}

Pedoman pelaksanaan merupakan acuan bagi pelaksana langsung di lapangan yang setidaknya mencakup (i) kriteria kelayakan pegawai; (ii) pengembangan kelembagaan; (iii) 
pembagian peran dan tanggungjawab setiap institusi; (iv) pengembangan sumberdaya manusia; (v) pengembangan big data dan pengamanannya; (vi) pendanaan; (vii) pemantauan dan evaluasi

Upaya pelaksanaan kebijakan bekerja dari rumah hanya dapat dilaksanakan jika tersedia pedoman pelaksanaan kegiatan yang dilegalkan melalui peraturan pimpinan daerah, baik peraturan gubernur, walikota maupun peraturan bupati.

\subsection{Peninjauan Kembali Rencana Tata Ruang}

Penerapan bekerja dari rumah dapat mengubah struktur dan pola ruang terutama disebabkan terjadinya perubahan bangkitan lalulintas yang berujung pada berubahnya pola pergerakan manusia dan barang. Selain itu, bekerja dari rumah yang purna waktu cenderung menafikan faktor jarak rumah dan kantor, sehingga mendorong maraknya perebakan kota (urban sprawl). Ketika kota belum mencapai titik optimal kepadatannya maka perebakan kota dapat menimbulkan ketidakefisienan pemanfaatan lahan.

\subsection{Penyediaan insentif dan insentif}

Sebagai konsep baru, penyediaan insentif bagi organisasi/perusahaan yang berkeinginan bergabung dalam skema bekerja dari rumah berupa pengurangan pajak, dan kemudahan lainnya dapat mendorong semakin banyaknya organisasi/perusahaan untuk bergabung. Tentunya disinsentif menjadi suatu kewajaran ketika terjadi ingkar janji.

\section{a. Kebijakan Organisasi/Perusahaan}

Kebijakan organisasi/perusahaan merupakan keseluruhan harapan pegawai dan pimpinan yang disepakati dan dituangkan secara tertulis dalam bentuk kebijakan. Keseluruhan tindakan berdasar pada kebijakan yang telah disepakati.

Dalam kebijakan beberapa hal penting sebaiknya tercantum, yaitu (i) kriteria kelayakan pegawai terlibat dalam skema bekerja dari rumah; (ii) pengaturan hal teknis seperti penjadwalan, dukungan perusahaan, kompensasi bagi pegawai yang tidak berpeluang bekerja dari rumah dan lainnya; (iii) penetapan ukuran kinerja pegawai; (iv) pengelolaan sistem komunikasi. Bekerja jarak jauh memudahkan timbulnya rasa curiga, dan kekhawatiran pimpinan dan pegawai terhadap kualitas komunikasi; (iv) penyediaan dukungan baik berupa penyediaan perangkat, dukungan teknis bahkan dukungan moral; (v) persyaratan keamanan, dan kenyamanan lingkungan kerja; (vi) pengembangan dan pengamanan data; (vi) pengamanan rahasia mitra kerja.

\section{b. Pelatihan kapasitas sumberdaya manusia}

Bekerja dari rumah merupakan konsep baru bagi kebanyakan pegawai, bahkan dalam konteks budaya pun ini merupakan hal baru. Untuk itu, pengenalan bertahap tentang bekerja dari rumah menjadi suatu keniscayaan agar pegawai dapat menjalani dengan baik.

\section{c. Pengembangan, pengelolaan dan pengamanan BIG Data}

Bekerja dari rumah sangat mengandalkan pertukaran data melalui daring antara pegawai dan kantor, dan sesama pegawai. Data yang dibutuhkan menjadi sangat banyak dan memerlukan pengaturan secara sistematis. Jika dalam bentuk yang sangat besar maka kita kenal sebagai BIG Data. Jika terjadi hambatan dalam penyediaan pertukaran data, maka produktivitas dapat menurun. 
Selain itu, pertukaran data melalui daring menjadi mudah untuk 'dimasuki’ oleh pihak luar, sehingga pengamanan data menjadi prioritas.

\section{Daftar Pustaka}

\section{Regulasi dan Panduan}

US Government. 2010. The Telework Enhancement Act (the Act). One Hundred Eleventh Congress of the United States of America at the Seecond Session. https://www.govinfo.gov/content/pkg/BILLS-111hr1722enr/pdf/BILLS$111 \mathrm{hr} 1722 \mathrm{enr}$. pdf diakses pada 6 Juni 2020.

US Office of Personnel Management. 2011. Guide to Telework in the Federal Government. https://www.telework.gov/guidance-legislation/telework-guidance/teleworkguide/guide-to-telework-in-the-federal-government.pdf diakses pada 6 Juni 2020.

\section{Disertasi dan Tesis}

Asgari, Hamidreza, 2016. On the Impacts of Telecommuting over Daily Activity/Travel Behavior: A Comprehensive Investigation through Different Telecommuting Patterns. Disertasi, Florida International University. Florida International University, 2015. https://digitalcommons.fiu.edu/etd/2182 diakses pada tanggal 30 Januari 2020.

DeRossette, Zachary Glenn, 2016. Variation in Job Performance Among Telecommuters. A thesis submitted to the faculty of San Francisco State University. San Francisco, California.

\section{Buku}

Overmyer, Scott P. 2012. Implementing Telework: Lessons Learned from Four Federal Agencies. IBM Center for The Business of Government.

\section{Makalah, dan Kertas Kerja}

Budhiekusuma, Noor Patria, Hadi, Sasongko Pramono, dan Winarno, Wing Wahyu, 2017. Peluang Pemanfaatan Telecommuting dalam Pemerintahan di Indonesia. Jurnal Pekommas, Vol. 2 No. 2, Oktober 2017.

Handy, S.L., and P.L. Mokhtarian, 1995. "Planning for Telecommuting: Planning and Policy Issues". Journal of the American Planning Association 61(1), pp. 99-111.

Higa, Kunihiko dan Wijayanayake, Janaka, 1998. Telework in Japan: Perception and Implementation. Tokyo Institute of Technology.

Huuhtanen P., 1997. The health and safety issues for teleworkers in the European Union. Consolidated report. European Foundation for the Improvement of Living and Working Conditions. Working Paper No:WP/97/29/EN.

Mello, J., 2007. "Managing Telework Programs Effectively". Employee Responsibilities and Right Journal, 19(4), pp. 247-261.

Mokhtarian, P.L., 1991. "An Empirical Analysis of the Transportation Impacts of Telecommuting". Proceedings (Vol. 1), 6th International Conference on Travel Behavior, Quebec City, Quebec.

Mungkasa, Oswar. 2020. Bekerja Jarak Jauh (Telecommuting): Konsep, Penerapan dan Pembelajaran. Bappenas Working Papers Vol. 3 No. 1 Tahun 2020.

Nilles, J.M., 1988. "Traffic Reduction by Telecommuting: A Status Review and Selected Bibliography”. Transportation Research, 22 A, pp. 301-317

Sampath S., Saxena S. and P.L. Mokhtarian, 1991. "The Effectiveness of Telecommuting as a Transportation Control Measure". Working paper, UCTC No. 78, University of California at Davis. 
Saxenaa, Samitra dan Mokhtarian, Patricia L., 1997. The Impact of Telecommuting on the Activity Space of Participants. Geographical Analysis, Vol. 29, No. 2, April 1997, The Ohio State University Press.

Siha, S. M., \& Monroe, R. W. (2006). Telecommuting's past and future: a literature review and research agenda. Business Process Management Journal, 12(4), 455-482. http://doi.org/10.1108/14637150610678078

Walls, M. and E. Safirova, 2004. "A Review of the Literature on Telecommuting and Its Implications for Vehicle Travel and Emissions". Discussion Papers DP-04-44, Resources for the Future.

\section{Artikel}

Afshar, Vala. 11 Mei 2020. Working from Home: the New "Normal". ZDNet. https://www.zdnet.com/article/the-average-productivity-loss-of-remote-work-is$1 /$ diakses pada 7 Juni 2020.

Ayuna, 2019. Flexi Time: Jenis, Aturan, dan Keuntungannya bagi Karyawan. https://sleekr.co/blog/flexi-time-bagi-karyawan/ diakses pada tanggal 8 Januari 2019.

Bayern, Macy. 13 Maret 2020. The 10 Rules Found in Every Good Remote Work Policy. TechRepublic. https://www.techrepublic.com/article/the-10-rules-found-in-everygood-remote-work-policy/?ftag=CMG-01-10aaa1b diakses 4 Juni 2020.

Cuttino, Ashley Prickett. 27 Maret 2020. 9 Telecommuting Tips for Employers as COVID19 Spreads Across the United States. OagleeTree Deakins. https://ogletree.com/insights/9-telecommuting-tips-for-employers-as-covid-19spreads-across-the-united-states/ Diakses pada tanggal 26 mei 2020

Hess, Melanie. 9 Maret 2020. The New Coronavirus Drives Need for Remote Work. Virtual Vocations. https://www.virtualvocations.com/blog/articles/current-events/thenew-coronavirus-drives-need-for-remote-work/ diakses pada 6 Juni 2020.

Leprince-Ringuet, Daphne. 20 Mei 2020. Back to the Office?; How You Should Manage the Return to Work after the Lockdown. ZDNet. https://www.zdnet.com/article/backto-the-office-how-you-should-manage-the-return-to-work-after-the-lockdown/ diakses pda 6 Juni 2020

Massey, Emily G. 30 April 2020. United States: The New Normal - Teleworking Challenges and Solutions. Ward and Smith, P.A. https://www.mondaq.com/unitedstates/employment-and-workforcewellbeing/925156/the-new-normal-teleworking-challenges-and-solutions diakses pada tanggal 2 Juni 2020.

Morikawa, Masayuki. 10 April 2020.COVID-19, Teleworking, and Productivity. VOX CEPR Policy Portal. Research-based policy analysis and commentary from leading economist.

Ohio University, 2015. Telecommuting Can Save Business Money. Online Master of Business Administration. https://onlinemasters.ohio.edu/blog/how-telecommuting-can-savebusinesses-money/diakses pada 9 Januari 2020

Wallen, Brian M. dan Wietrzychowski, Michael. 27 March 2020. United States: Telecommuting in the Time of Covid-19. Schnader Harrison Segal \& Lewis LLP https://www.mondaq.com/_unitedstates/employee-benefits-compensation/ Internet 908454/telecommuting-in-the-time-of-covid-19 diakses pada tanggal 1 Juni 2020.

Eurofound. European Foundation for the Improvement of Living and Working Conditions https://www.eurofound.europa.eu/data/percentage-of-workers-doing-teleworkand-ict-based-mobile-work diakses pada 6 Juni 2020. 